\title{
A FILOSOFIA MORAL NEGATIVA DE THEODOR W. ADORNO*
}

\author{
GERHARD SCHWEPPENHÄUSER*
}

\begin{abstract}
RESUMO: O problema da universalização na filosofia moral não foi de forma alguma tematizado por Adorno. Contudo, há elementos nas suas obras que nos possibilitam refletir sobre esse tema. Tendo por base os escritos de Adorno, e esta é minha tese, pode-se estudar como a ambivalência das diretrizes normativas é integrada numa teoria crítica da moral sem que se renuncie a uma pretensão de validade crítico-normativa.
\end{abstract}

Palavras-chave: Teoria crítica. Filosofia moral. Theodor W. Adorno. Ética.

\section{The negative MORAL Philosophy OF TheOdor W. Adorno}

ABSTRACT: Although Adorno did not approach the issue of universalization in moral philosophy, some elements in his complete works allow us to think about it. My thesis is that, from his writings, we can study how the ambivalence of the normative rules can be integrated into a critical theory without losing their pretension to a critical-normative validity.

Key words: Critical theory. Moral philosophy. Theodor W. Adorno. Ethics.

* Tradução de Antônio A. S. Zuin, Fábio A. Durão e Newton Ramos-de-Oliveira, com revisão de Bruno Pucci e Douglas Garcia Alves Júnior.

** Professor da Bauhaus Universität (Weimar).E-mail: g.schweppenhaeuser@gmx.de

Educ. Soc., Campinas, vol. 24, n. 83, p. 391-415, agosto 2003

Disponível em <http://www.cedes.unicamp.br> 
o debate sobre a ética, pode-se obter uma boa visão geral quando se opta pelo consentimento ou pela recusa com relação ao universalismo filosófico-moral. De um lado, encontram-se Hare, Rawls e Habermas, do outro Taylor, Rorty e Bauman, e, entre ambos os grupos, Nussbaum, Benhabib e Honneth. $\mathrm{O}$ que tem Adorno a ver com isso? Suas reflexōes sobre as aporias de uma vida reta e da ação racional colocam-se no contexto da antiga teoria crítica da sociedade, que não lidava diretamente com a ética. $\mathrm{Na}$ Minima moralia, ele chamou a atenção para a relação interna entre moral e repressão e defendeu a tese de que as normas e os princípios morais, da Antiguidade até os dias de hoje, foram duplicações teóricas da dominação social e que, na totalidade falsa, que é um desdobramento da sociedade capitalista, não pode haver uma vida reta (Adorno, 1980, p. 210 e 43). O problema da universalização na filosofia moral não foi absolutamente tematizado por Adorno. Contudo, a meu ver, há elementos nas suas obras que nos possibilitam refletir sobre esse tema. Adorno pode nos ajudar a entender o universalismo filosófico-moral na sua ambivalência,o qual costuma ser negligenciado na controvérsia ética entre universalistas e particularistas (Schweppenhäuser, 1995).

As teorias deontológicas da moral, ${ }^{1}$ tal como a de Rawls, que segue a linha da ética do discurso, reduzem a esfera do que pode ser objeto dos discursos práticos ao debate público de questôes da justiça. Apenas assim, segundo ele, seria possível encontrar princípios normativos capazes de serem generalizados, e que pudessem reivindicar, em busca de legitimidade, uma pretensão universal de validade. A esfera, na qual os conceitos de felicidade e de vida boa se localizavam, de acordo com as éticas pré-modernas, é hoje delimitada como uma questão privada. Os críticos da filosofia moral universal optam por formular éticas que se baseiam exatamente nessa esfera, e que são válidas apenas para o interior de comunidades demarcadas. Eles fracassam quanto ao objetivo de engendrar uma normatividade crítica, sem a qual a reflexão ética já não se impõe convincente, já na esfera interior das sociedades isoladas, que dirá, de fato, quando inseridas no "clash of civilization" (Huntington). Mas as abordagens universais fracassam na sua restritiva divisão de trabalho ao reduzir a questões de justiça o objetivo da mediação de questões gerais da correção nas questões específicas da vida boa, as quais uma filosofia moral moderna não pode perder de vista (Benhabib, 1992, p. 224 e ss.). 
O "moral point of view", em torno do qual a ética discursiva foi centrada, com referência a Kohlberg, delineia-se por meio de um interesse imparcial com relação à justiça e ao bem-estar de todos os sujeitos capazes de agir, além de ser demarcado por meio da prontidão e competência para a criação de consenso intersubjetivo concernente às questôes normativas em disputa. Esse nível forma ontogeneticamente o mais alto padrão mensurável de desenvolvimento do juízo moral; já filogeneticamente ele é discutido como uma idéia regulativa da racionalidade concretizada. Aquilo que é aceito no plano filosófico-moral corresponde à formação dos princípios morais universais e à persuasão dos sujeitos, cuja pretensão de validade pode ser decidida apenas no discurso. O projeto do esclarecimento filosófico-moral na modernidade consiste em validar os princípios morais e em estabelecer as regras de jogo obrigatórias do discurso normativo. Porém, na perspectiva da filosofia moral negativa de Adorno, coloca-se a questão se de fato podemos nos dar ao luxo de renunciar à crítica dialética dos próprios princípios. Uma suposição básica da "Dialética do esclarecimento" diz o seguinte: a realização universal do pensamento esclarecido é obstaculizada, pois a reflexão não se realiza no seu lado sombrio. Conceitos como o de liberdade, imparcialidade, justiça e atenção têm um índex histórico que os vincula com o seu reverso. Eles estão inscritos no contexto da história de dominação da sociedade burguesa e por isso portam sempre, na condição de modernos coincidentiae oppositorum, opostos coincidentes, também o contrário daquilo pelo qual eles explicitamente respondem. A liberdade é confundida com a sua ausência quando ela substancialmente se transforma, para os indivíduos, apenas na liberdade de vender a própria força de trabalho como mercadoria. A imparcialidade pode significar, numa sociedade composta de partidos, a tomada de partido pela ordem existente. A atenção e o reconhecimento do outro nunca podem ser totalmente separados das linhas condutoras do comportamento por meio das quais os aprendemos: obediência e medo. Se a justiça for compreendida como o princípio de "a cada um, aquilo que lhe cabe", isso significa também que alguém é apenas aquilo que lhe compete sob as relaçôes sociais existentes. (Esse princípio do suum-cuique é, portanto, per se problemático, e não apenas na sua perversão como lema do campo de concentração nazista em Buchenwald, diante dos portóes de Weimar, que foi liberado pelo exército americano em maio de 1945). 
Foucault, em sua genealogia da moral, chegou a resultados próximos aos de Adorno, embora tenha tirado outras conclusões. Sua crítica genealógica e arqueológica do poder e da razão cria ambigüidades normativas, porque suas pretensões de validade "se reduzem, de forma funcionalista, a efeitos do poder" e o "dever (...) é, de forma naturalista, reconduzido ao ser" (Habermas, 1986, p. 325). Tendo por base os escritos de Adorno, e esta é minha tese, pode-se, por outro lado, estudar como a ambivalência das diretrizes normativas pode ser integrada numa teoria crítica da moral sem que se renuncie a uma pretensão de validade crítico-normativa que é refletida de modo filosófico-moral. Kant, Hegel, Marx, Nietzsche e Freud são as fontes para a crítica ideológica imanente da filosofia moral de Adorno; para ele, realizar a crítica ideológica não significava que, junto com a indicação de seus repressivos custos de produção, ela devesse ser jogada no lixo. Isso também não queria dizer que a filosofia moral fosse explicada como supérflua.

Adorno não se ocupou de denúncias céticas da racionalidade da filosofia moral burguesa como ideologia dominante. Sua contribuição para a discussão filosófico-moral atual poderia ser reconstruída da seguinte forma: é do interesse de todos os homens, no que se refere à concretização de uma regulamentação racional e moral de suas interações sociais, que a ambivalência das intuições éticas permaneça na consciência. Pois só aquilo que conhecemos podemos mudar. Apenas quando refletimos sobre a ambivalência das categorias morais podemos evitar ser dominados por seu lado repressivo, o que nos impediria de usar suas forças libertadoras para a organização autônoma da vida social. Podemos aprender muito, com os textos de Adorno, sobre a razão por que o potencial emancipatório da normatividade guiada por princípios é posto em risco também por meio de sua própria dialética imanente. É apenas a partir de tal perspectiva que esse potencial só pode ser atualizado.

\section{Ética e filosofia moral}

As reflexóes normativas fundamentais da teoria crítica de Adorno, as quais nem sempre são claras em seus escritos publicados, podem ser estudadas por meio das anotações de suas aulas que foram ministradas em Frankfurt sobre o tema "problemas da filosofia moral", primeiramente nos anos de 1950 e, posteriormente, no início dos anos de 1960. Chama a atenção aqui, em primeiro lugar, que Adorno 
tenha se dedicado a reflexões filosófico-morais, mas tenha explicitamente se negado a elaborar uma nova ética. ${ }^{2}$

Quando se fala sobre "ética" atualmente, via de regra pensa-se em uma "teoria de reflexão da moral" (Luhmann, 1989). A expressão "ética" tem assim o mesmo significado que "filosofia moral". Entretanto, ambas as expressões são freqüentemente utilizadas para delinear uma diferença de conteúdo. Pensa-se que "ética e moral" se referem ao agir do mundo da vida, ao passo que as expressōes "ética e filosofia-moral" se referem à reflexão filosófica sistemática da qual esse agir é objeto.

As reflexões de Adorno sobre identidade e diferença dos conceitos "ética" e "moral" tomam outra direção. Se o conceito de moral é utilizado, seria de se presumir que já houvesse uma concordância entre a moralidade pública e a individual. O discurso da "moral", para Adorno, tinha implicaçôes restritivas, até mesmo repressivas, na esfera da sexualidade. Já quem preferisse falar sobre "ética" sugeriria, em vez disso, uma referência à pessoa, à qualidade do humano, pois na ética não conta o agir conforme as representaçôes morais públicas, mas sim um agir que segue seu próprio caráter, um particular "ser-assim". Porém, ao se pensar dessa forma, o termo ética revelou-se, segundo Adorno, meramente uma "má consciência da consciência" (Adorno, 1996, p. 28), pois a correta pretensão de que as moralidades pública e privada deveriam coincidir é resignadamente deixada de lado. Para Adorno, no clima intelectual dos anos 50, impôs-se uma tendência ontologizante no conceito "ética": uma índole a ser encontrada do homem, seu ser-assim, a ponto de se tornar um critério normativo. "O conceito de ética", observa Adorno em suas aulas nos anos de 1956/57, "é mais benquisto que o de filosofia moral. Ele não soa tão rigoroso, parece ter um sentido mais elevado, mais humano. (...) A ética é algo suavizado, descompromissado (...). E como nós certa vez o obtivemos, desse fato deve ser derivado o modo como devemos nos comportar". Adorno preocupa-se em acentuar, na tradição do esclarecimento, a oposição entre natureza e racionalidade moral. "A ordem moral (...) se relaciona com a razão, por meio daquilo que nos eleva acima da natureza. $\mathrm{O}$ ethos $^{3}$ encontra-se em intensa oposição, segundo a filosofia moral kantiana" (Adorno, apud Schweppenhäuser, 1993, p. 7). E ela foi um ponto de referência obrigatória para suas próprias reflexōes, de tal modo que Adorno preferiu o conceito de moral. O problema básico da moral foi para ele "a relação entre lei e liberdade" (Adorno, 1996, p. 30). 
Para Adorno, a filosofia moral foi há tempos condenada à esfera da vida privada, uma vez que vivemos numa sociedade individualista (idem, ibid., p. 261). Ele identificou, de forma conseqüente com a tradição do esclarecimento, como problema básico da filosofia moral a relação entre o indivíduo e a totalidade, o universal: o "problema central de toda filosofia moral" seria "a relação entre o particular, ou seja, os interesses particulares, as formas de comportamentos dos indivíduos particulares, e o universal que se encontra em oposição com tal particular". Mas o universal não é tão facilmente condenável, pois "também nele sempre esteve contida a pretensão da concretização de uma sociedade justa (...) na qual coação e violência não mais existiriam" (idem, ibid., p. 33 e ss.). Este é o horizonte normativo das reflexões adornianas da filosofia moral. Por isso, para ele, a questão fundamental da filosofia moral era a seguinte: "De que modo os interesses particulares e as pretensões de felicidade poderiam ser conduzidos, em concordância com certos interesses objetivos, originando normas obrigatórias para o gênero humano". Porém assim, pensava Adorno, recairíamos sempre na esfera das "relações de tensão" e das "contradições" (idem, ibid., p. 27). O "problema social da forma de disjunção do interesse universal e particular" (idem, ibid., p. 35) seria, ao mesmo tempo, o problema da filosofia moral. Nisso, podemos seguir até hoje as ponderações de Adorno. As realidades sociais caracterizam-se pelo fato de que interesses particulares se colocam como interesses gerais. Os indivíduos devem representar seus interesses particulares, como se o interesse universal e o particular coincidissem. Enquanto esse estado de coisas se mantiver, encontramo-nos numa aporética situação de contradição. Por isso, a questão sobre a vida reta ou boa, refletiu Adorno, só poderia ser respondida por meio da "negação determinada" e isto, para ele, significava a práxis: nós poderíamos ainda assim tentar existir decentemente, mesmo quando o estado geral social, na condição do todo, impede-nos de fazê-lo (idem, ibid., p. 22, 260 e ss.). A ética nietzscheana e kierkegaardiana da existência, a qual sempre se serviu da dimensão estética e que foi reativada por Michel Foucault, foi refletida por Adorno na forma da negação determinada, pois ele observou na resistência contra uma socialização heterônoma (e isso significa também uma resistência às formas socialmente sancionadas da moral repressiva) a chance de se agir como representante da vida reta, a única que seria possível no todo falso (idem, ibid., p. 249 e ss.).

Entretanto, no nível da teoria crítica, tal ética representativa de uma existência de resistência não podia mais ser formulada como 
"ética". Ela se deixa reconstruir como momento de uma filosofia moral crítica ou, como denominei, uma filosofia moral "negativa". Gostaria de apresentar tal argumento mais pormenorizadamente com o auxílio de seis aspectos: 1) a teoria do "impulso moral"; 2) a "aporia" e a "negação determinada" da moral (com base na interpretação adorniana de Nietzsche); 3) o teorema da "modernidade"; 4) a relação de Adorno com Kant e Hegel; 5) o "novo imperativo categórico" após Auschwitz; 6) e, finalmente, as implicações de uma teoria crítica do universalismo filosófico-moral.

\section{O impulso moral}

A teoria adorniana do impulso moral deve ser observada no contexto de dois casos ilustrativos da tradição filosófico-moral nãocognitivista, a saber: a determinação da compaixão segundo Rousseau e Schopenhauer. Rousseau estabeleceu dois princípios para a alma humana, os quais seriam, no "homme naturel", a precondição de sua socialização cultural e moral: de um lado, o egoísmo da autoconservação, e de outro a "aversão natural", "de se ver qualquer ser dotado de sentimento, especialmente um que nos seja similar, morrer ou sofrer" (Rousseau, 1983, p. 71 e ss.). Rousseau ainda não determina, é claro, a "commisération" como princípio moral, mas sim como um impulso moral, de início, antropologicamente indiferente. Já em Schopenhauer se encontra a "aversão" diante da contemplação do sofrimento alheio, agora concebida de forma positiva, como "aquela estranha predisposição (...) através da qual a dor de alguém é compartilhada pelo outro". A compaixão seria o único princípio moral reconhecível racionalmente, embora não seja por si próprio racional: "A única fonte das ações desinteressadas". Seria pois a "verdadeira base da moralidade", à qual Schopenhauer opõe a máxima kantiana universalizável da razão, pois apenas por meio daquela haveria a justiça e o amor entre os homens (Schopenhauer, 1977, p. 285; Schmid Noerr, 1997).

Todavia, Adorno não se ateve à instauração da compaixão como princípio moral afirmativo. Ele não procurou um fundamento para a moral, mas sim um fermento de uma solidariedade mimética que não rivalizasse com a racionalidade do normativo, mas que devesse ser elaborada na sua precária e evidente combinação, porém de forma transparente, com tal racionalidade. Sua teoria do impulso moral foi a tentativa de determinar, no indivíduo, motivos reflexivos e somático- 
miméticos como elementos de ação ante desafios concretos. "As questōes morais colocam-se de forma sucinta", diz-nos a Dialética negativa,

em afirmaçōes como: Não se deve torturar, não deve existir nenhum campo de concentração, porém isso continua a existir na África e na Ásia enquanto a humanidade civilizada permanece, como sempre, inumana para com aqueles que ela desavergonhadamente estigmatiza como não civilizados. Mas a conclusão seria falsa se um filósofo da moral se apoderasse de tais lemas e se regozijasse, pois assim teria surpreendido os críticos da moral, que, eles próprios, também citaram os valores anunciados com satisfação pelos filósofos da moral; a conclusão final seria falsa. São verdadeiros como impulsos, uma vez que denunciam que em qualquer parte se tortura. Não podem ser racionalizados; como princípios abstratos cairiam de imediato na má infinitude de sua dedução e de sua validade. (Adorno, 1984, p. 281)

No centro da reflexão de Adorno há um motivo mimético. O núcleo do impulso moral seria o "medo físico nu e cru, e o sentimento de solidariedade com os corpos torturáveis, nas palavras de Brecht" (idem, ibid.). Em 1941, Bertold Brecht mencionou o corpo torturável na poesia dedicada a Benjamin com o seguinte título: "Por ocasião do suicídio do fugitivo W.B." (Brecht, 1982, p. 829). "A moral sobrevive só no motivo materialista nu e cru", observou Adorno (1984, p. 358). É por isso que não se encontra em seus textos, como em Ludwig Wittgenstein, a reflexão analítico-lingüista fundamentalmente cética sobre a possibilidade de empatia com o sofrimento do outro. A compaixão, formulou Wittgenstein, "é uma forma de convencimento de que o outro tem dor". Mas com essa definição foi colocada, em primeiro plano, a questão sobre o "critério de identidade" da pessoa para a filosofia do jogo da linguagem. Seria difícil representar a dor do outro segundo a "imagem de si próprio", pois "devo representar para mim mesmo, de acordo com o sofrimento que sinto, aquele que não sinto" (Wittgenstein, 1995, p. 371, 360 e 376). Niklas Luhmann desenvolve raciocínio semelhante por ocasião da reflexão sobre a dor e sua comunicação: que os indivíduos seriam fundamentalmente mônadas incompatíveis entre si, mas que ainda assim poderiam comunicar-se. Porém, se não se trata absolutamente do problema da comunicabilidade de uma experiência, a qual não tem fundamentalmente uma natureza lingüística, mas que, como enfatizou Adorno, por meio de um conceito que remete ao contexto da ética material dos valores de Max Scheler, não é redutível ao espírito e, sim, ao natural-sensível "momento de entrada na moral" (Adorno, 1984, p. 358) - se se trata de um impulso que deve remeter 
à reflexão, então algo de totalmente outro se encontra em jogo: o problema da possibilidade de uma práxis moral. E, segundo Adorno, ela é precária.

\section{Aporia e negação determinada da moral}

A aporia da moral pode ser descrita, da perspectiva de sua teoria crítica, da seguinte forma: a moral sempre apresenta concomitantemente elementos emancipatórios e repressivos - e ambos só podem se fazer valer sempre por meio da relação que um tem com o outro. Se não existisse o conceito de liberdade, não teríamos nenhum conceito de preceitos morais, os quais também não permitiriam que se tirasse nenhuma conseqüência. Nesse contexto, uma vida humanamente digna seria impensável. Mas os preceitos morais apresentam-se necessariamente como imperativos que reivindicam validade incondicional. Sua gênese desaparece na sua validade. $\mathrm{O}$ único manancial de força que os preceitos morais têm é a sua autoridade convencionalmente estabelecida. Isso significa que a reflexão moral tanto fundamenta quanto reduz a liberdade de ação no indivíduo. A esfera do impulsivo e do mimético deve ser reprimida. Contudo, apenas porque como pessoas capazes de agir podemos articular e realizar nossos interesses, também os de validade universal, a moral pode se revelar como instrumento de opressão e como precursora da liberdade.

Diante disso, Adorno procurou defender a promessa da moral contra a sua inevitável autodestruiçãa. Ele observou a ação de um antagonismo na moral que reproduz o antagonismo social entre os interesses do particular e do universal. Isso deveria também encontrar sua expressão na posição do filósofo da moral quanto ao seu próprio fazer teórico. Já nas suas aulas ministradas em 1956/57, Adorno mencionou uma "dupla posição da moral" que ele, na condição de teórico crítico, deveria tomar para si. Com isso ele queria dizer "que devemos aceitar moralmente o todo na medida em que, por um lado, ele é transparente na relação com a humanidade que se concretiza (...) e, por outro lado, transparente com relação à liberdade e à autodeterminação do indivíduo, e que toda moral, no que tem de repressora e repressiva, pode ser criticada”. Essa é a contradição imanente da moral: por um lado, ela conduz os homens para a responsabilidade, atribui-lhes a liberdade de ação que eles não teriam de outro modo, por outro lado, a moral, na condição de crítica do 
agir existente do homem é, ao mesmo tempo, "representante de uma liberdade que ainda está por vir". Portanto, na condição de filósofo, deve-se tanto ser em favor da moral como contra ela. A crítica moral não deveria dirigir-se nem a uma contramoral afirmativa nem à negação abstrata de toda moral - tal como no caso de Nietzsche, para o qual ambos os estados transformam-se um no outro. Tal crítica deveria sim se fundamentar unicamente na "negação determinada" da moral, de tal modo que "a colocássemos em confronto com seu próprio conceito, que pudéssemos questionar: a moral é moral? Sãolhe suficientes os princípios que contém em si mesma?" (Adorno, apud Schweppenhäuser, 1993, p. 177 e 179).

A negação determinada da moral, à qual Adorno se refere, não deve chegar a extinguir a moral, mas sim evidenciar quando e até que ponto ela própria se torna imoral. $\mathrm{O}$ método da negação determinada é, para Adorno, um método crítico e não a fundação idealista de uma nova positividade, tal como para Hegel, ou seja, ele não significa uma transformação da moralidade numa moralidade substancial, mas sim a negação da negação no sentido formulado por Marx. A filosofia moral tradicional, na sua forma idealístico-abstrata, negava os fundamentos históricos e sociais com os quais ela se relacionava. Essa negação foi novamente negada por Adorno para que a forma produtiva da filosofia moral pudesse ser negada, ao mesmo tempo que mantida, pela teoria crítica da moral.

É por isso que não é estranha a repreensão de Adorno a Nietzsche por este ter negado a moral de forma abstrata. Segundo Adorno, Nietzsche condena os conteúdos da filosofia moral ocidental como um todo, sem diferenciar seus aspectos ideológicos dos verdadeiros. A conseqüência desse procedimento é que as próprias atribuições de valor de Nietzsche reproduzem os preceitos morais que ele presumia ter superado, apenas com valores trocados. Numa aula de 1963, Adorno criticou Nietzsche por permanecer na "negação abstrata daquela moral burguesa", ou seja, "daquela moral tornada ideologia, tornada máscara para os negócios abjetos". Ele perdeu a chance "de alcançar, a partir da solução dos problemas morais particulares com os quais se deparou, uma formulação da idéia da vida reta”. Em vez disso, Nietzsche confrontou a ideologia moral "com uma nova moral positiva que nada mais é do que mero reflexo negativo da moral rejeitada pelo próprio Nietzsche" (Adorno, 1996, p. 256).

Contra este argumento poder-se-ia objetar que Nietzsche não sem razão concebia sua crítica como "a auto-superação da moral" 
(Nietzsche, 1977, vol. 1, p. 1.015), cuja força motriz era um conceito de moralidade que não se queria deixar corromper, e cujo impulso moral protegeria contra sua instrumentalização e sua ideologização. Mas quem aspira à "auto-superação da moral” (idem, ibid., vol. 2, p. 598) não pode rejeitar a filosofia moral como um todo. Portanto, o "imoralismo" de Nietzsche foi a conseqüência de sua moralidade. É claro que Adorno observou essa contradição e sempre a enfatizou, mas sua crítica referiu-se à forma de condução e não ao próprio programa de Nietzsche. E essa crítica aqui se aplica, pois Nietzsche caracterizou todo esforço filosófico-moral, de Platão a Kant e Schopenhauer, como um sintoma da "décadence" e não admitiu a possibilidade da filosofia moral nem sempre ter permanecido como véu ideológico, mas sim ter freqüentemente se tornado um impulso para a transformação da realidade e, portanto, na pretensão para a construção racional da realidade social, e assim criar a base da felicidade humana em uma prática compatível com a razão (Schweppenhäuser, 1988). Para Nietzsche, a racionalidade moral era meramente a repressão regressiva dos instintos vitais, sendo o imperativo categórico uma "tartüfferie" ${ }^{4}$ e o conceito de liberdade inteligível algo "sem sentido" (Nietzsche, 1977, vol. 2, p. 570 e 977). Deve-se concordar com Adorno, quando censurou Nietzsche pelo seu desejo de renovação das normas feudais, já que, em seu culto da nobreza e da virtude de uma nova moral aristocrática, a crítica das representaçôes morais existentes transformouse numa visão afirmativa da injustiça social e das relaçôes de violência (Adorno, 1963, p. 257). Mas ele não o condenou, como o fez George Lukács, por causa disso. Adorno, pelo contrário, tentou descobrir um núcleo racional nos erros de Nietzsche. $\mathrm{Na}$ "brutalidade da filosofia moral de Nietzsche", observou, há sempre a verdade de que "numa sociedade, que é essencialmente baseada na violência e na exploração, aquela violência não racionalizada, confessa, que se olha na cara, e, se se pode dizer assim, uma violência sem perdão, ainda é menos culpada do que aquela que se racionaliza como o Bem" (Adorno, 1996, p. 258). Numa transmissão radiofônica, juntamente com Max Horkheimer e Hans Georg Gadamer, Adorno, após regressar à Alemanha libertada, já teria se referido ao caráter irônico e ambíguo da forma de exposição em Nietzsche. Adorno enfatizou que, baseando-se nisso, o conceito de Nietzsche de uma "humanidade liberta" apresenta uma imagem invertida da humanidade ainda aprisionada, a saber, na imagem dominada pela "mentira" e pela "moral convencional" que ele deseja delinear 
quando postula a destruição da convenção. Portanto, Adorno deduziu o seguinte: "O modelo ideal de liberdade manifesta-se por detrás do culto, no primeiro plano, da repressão" (Horkheimer, 1989, p. 115).

$\mathrm{O}$ argumento central da metacrítica de Adorno à crítica da moral nietzscheana é que Nietzsche, com sua determinação da moral dos escravos, imputa a falsa aparência àquelas relaçôes sociais de poder, cuja presença Nietzsche, como quase nenhum outro pensador, desvelou até no microcosmo psíquico dos homens. O que em Nietzsche vitalisticamente seria representado e hipostasiado como manifestação da vontade de poder, portanto algo essencialmente substancializado, deveria ao invés disso ser mais uma vez desmistificado como aparência necessária a partir da perspectiva de uma libertação, possível, da dominação.

Nietzsche não compreendeu que aquilo que ele criticou como moral escrava foi, na verdade, sempre a moral do senhor, a saber, a moral imposta pela dominação dos oprimidos. Se sua crítica fosse tão conseqüente como ela deveria ser e como ela, de fato, não é - porque o próprio Nietzsche permanece envolto no feitiço das relações sociais existentes, porque ele examinou os homens tomando como base o que se tornaram, mas não examinou a sociedade a partir daquilo que os fez assim -, então essa crítica deveria se dirigir às condiçôes que determinam os homens, que os tornaram, que nos tornou, cada um de nós, o que somos. (Adorno, 1996, p. 258)

A crítica imanente de Adorno da moral e da filosofia moral é, portanto, orientada em última instância pela crítica de Marx da forma moral, que a entende como uma "forma de servidão voluntária" (Haug, 1986, p. 46), a qual contém, ao mesmo tempo, o potencial de autonomia. Mas Adorno atribuiu um grande valor a Nietzsche ao salientar que ele teria ido mais a fundo nos mecanismos do ideológico do que o marxismo.

\section{Teoria da modernidade}

Quanto ao projeto da ética imanente de Adorno, impóe-se a comparação com uma posição no discurso atual da ética que se assemelha em alguns pontos à filosofia moral negativa de Adorno, sobretudo no julgamento do caráter coercitivo e normativo das exclusôes repressivas da forma de racionalidade moderna. Refiro-me à "ética pós-moderna" da socióloga Zygmunt Bauman, vencedora do 
Prêmio Adorno da cidade de Frankfurt em 1998. Mas apresenta também diferenças cruciais, sobretudo quando Bauman deixa de lado a crítica imanente do moderno (Schweppenhäuser, 1999). Isso combina bem com sua teoria do moderno. A "substância" do moderno em sua prática política, social e intelectual consiste, segundo Bauman, no "esforço de resolver a ambivalência" (Bauman, 1992, p. 20). A marca do pensar e do agir seria o esforço pela definição exata e pela classificação lógica. $\mathrm{O}$ que não se encaixa é oprimido e extinto. O quadro tenebroso é o caos, o objetivo, a ordem, e a realização do projeto de domínio da natureza, nascido do medo, é o extermínio do estranho e do outro por assassinato em massa e de acordo com um plano. O moderno oprime e expulsa a ambivalência e, assim, produz a ordem por meio da força. Aos olhos de Bauman, o holocausto foi seu triste clímax e o socialismo realmente existente, sua última trincheira. A ele se opõe Bauman defendendo que o pós-moderno daria "uma chance ao moderno" porque acolheria a ambivalência (idem, ibid., p. 313). A pós-modernidade, portanto, representaria assim uma nova chance também porque deixaria para trás a atitude defensiva dos modernos e sua "razão não-emocional e calculista" contra a espontaneidade dos homens e sua condição caracterizada por pulsões e impulsos; teria concluído por intuiçãao que o "reencantamento" do mundo é a resposta adequada às ilusôes perdidas dos modernos. Uma ilusão central é a crença de se estabelecer um código ético universal e obrigatório. Hoje os filósofos da moral aprenderam "a aceitar a contingência", a "reconhecer as ambigüidades" e a compreender "a intuição moral" do indivíduo como última instância da moral (idem, 1995, p. 56 e 57). O fundamento de tal concepção é a "visão do pós-moderno como moderno modernizado" (Bonß, 1993 , p. 28). O problema consiste, na pior das hipóteses, segundo Bauman, no risco de levar a uma indiferença que se orienta ao mercado.

Bauman é uma advogada da ambivalência, que representa seus interesses contra o moderno e que os vê tendencialmente superados de forma positiva no pós-moderno. Para Adorno, no entanto, o próprio moderno era ambivalente. Mas só seria possível determinar metodicamente pela dialética, pois os conflitos da realidade social nunca ficam imobilizados em ambivalências; desenvolvem uma dinâmica destruidora, na qual os opostos se tornam uns nos outros. Adorno não queria conservar a ambivalência, mas, sim, decifrá-la como índice da heteronomia social 
ainda não superada. Por causa disso, dificilmente acolheria o pósmoderno como trampolim para a autodeterminação individual.

Adorno era um crítico dialético do moderno - no duplo sentido do genitivo: subjetivo e objetivo. Sua crítica do moderno é a de um filósofo que pertence à modernidade e não abandona suas intençôes normativas, mas quer mostrar como este, mesmo contra sua vontade, as abandona. Trata-se, para ele, de compreender como a normatividade da modernidade, como ideologia liberal da liberdade formal das relaçóes de troca na sociedade mercantil, vence até a morte, ou como, de forma derrotista, introduz sua própria queda, antes mesmo de ela ser testada compreensiva e permanentemente na sociedade real (Brunkhorst, 1990). A Dialética do esclarecimento reconstruiu o desencantamento do mundo no racionalismo ocidental moderno como "rota de fuga do sujeito diante das forças míticas" (Adorno, 1981, p. 64). Tais forças, é claro - e este é o ponto central do texto -, retornariam transformadas de sua repressão no período final do esclarecimento. O triunfo do domínio da natureza por meio da racionalidade instrumental-tecnológica acaba conduzindo ao fato de que relaçôes sociais feitas pelos homens, baseadas nas regras do domínio racionalizante da lógica da troca de mercadorias, agora apareçam como relações de uma segunda natureza imutável. No entanto, com a diferença de que as forças destrutivas por elas liberadas coloquem na sombra tudo o que a primeira natureza traga à tona. Eis o que Adorno e Horkheimer queriam dizer com o reencantamento, o que faz de seu objeto a crítica necessária da auto-reflexão da racionalidade. $\mathrm{O}$ reencantamento é aqui um menetekel, um aviso, e não uma palavra mágica como em Bauman.

Como Adorno, Bauman reflete também sobre o contexto de moral e dominação. Nos dois autores, a filosofia e a sociologia da moral interpenetram-se, o que para os administradores acadêmicos da filosofia constitui um horror materialista, e para os sociólogos cônscios de sua posição social, uma suspeita de metafísica. É claro, no conceito de desencantamento separam-se os espíritos: o que para Bauman é a libertação do domínio, Adorno teria descrito como seu processo transformado de perpetuação. Para Bauman, o adestramento racional da estrutura pulsional por meio das normas morais teria representado sempre a mera racionalização da dominação social, cujo desaparecimento aparece para a consciência pós-moderna conseqüentemente como crescimento da liberdade. Adorno não procede assim tão reducionisticamente. Segundo Bauman, o "postulado da universali- 
zação" era apenas "um reflexo da prática moderna da universalização". Seu conceito de universalismo é caracterizado por uma ambigüidade quanto aos significados político-sociais e filosófico-morais. Por universalização política, Bauman entendia "as ambições uniformizantes e as práticas do Estado moderno". A autoridade moral absoluta [incondicional] à qual ele aspirava pressupunha historicamente "apenas reconhecer as regras morais que passassem no teste de princípios universais, extemporâneos e extraterritoriais" (Bauman, 1995, p. 65). Bauman não recua diante de uma confluência do universalismo filosófico com o imperialismo: "Impérios de soberania ilimitada e indiscutível e a verdade de irrestrita e indiscutível universalidade eram as duas armas com as quais a modernidade pretendia dar forma ao mundo segundo o plano de uma nova e perfeita ordem" (Bauman, 1992, p. 310). O enfraquecimento dos fundamentos comunitários, territoriais e históricos válidos do julgamento moral pelo processo de estandardização da racionalidade ocidental é, para Bauman, uma espécie de colonização interna. "A busca febril pela 'fundamentação' das regras morais", defende, surgiu nos modernos de uma necessidade "de convencer os dominados". "A compulsão legal tinha, de fato, apenas uma chance de ser aceita com pequena resistência se o direito, em cujo nome foi efetivada, pudesse ser apresentado como algo mais do que um capricho do legislador" (Bauman, 1995, p. 102). A formalidade dos princípios e a discursividade das regras morais teriam a função de emprestar-lhes a aparência de legitimidade; por causa disso a filosofia moral se serviria da analogia com o Direito.

\section{Kant e Hegel}

Adorno também viu este lado da história dos vencedores como interiorização da dominação. Ele usou Freud em um acerto de contas com Kant, em relação aos custos de produção de sua rigorosa teoria moral, que por meio da internalização da dominação a perpetuava e que, pelos ciclos de repressão e retorno da violência, em última instância levaria ao fracasso da cultura (Adorno, 1984, p. 267 e ss.). Mas ele não via apenas isso, via também o lado ocultado: a idéia crítica da autonomia, o conteúdo de verdade dos postulados morais. Isso é freqüentemente apresentado equivocadamente nos estudos relativos a Adorno e Kant. Toma-se pelo todo a crítica - com certeza algumas vezes injusta - que acentua no imperativo categórico de Kant 
o momento de sublimação repressiva da instância psíquica do superego e, assim, negligencia-se que Adorno, ao contrário, critica Freud a partir de Kant. A recusa de Kant em submeter a consciência a uma crítica genético-psicológica encontra aprovação em Adorno, porque este reconhece aí a objeção de direito da aspiração moral de validade contra uma dissolução relativista na psicologia. O conteúdo de verdade, crítico e antecipador, de uma filosofia moral racionalmente estabelecida não pode ser atribuído à subjetividade, sempre danificada, da "personalidade empírica". Esta não pode ser o critério pelo qual se meça a moralidade. Adorno queria dizer que a pretensão de validade da lei moral kantiana conteria a antecipação de uma forma livre de socialização de indivíduos autônomos que apenas então seriam, de fato, capazes de agir moralmente. Como "núcleo" da teoria da liberdade kantiana, ele indicava "a idéia irreconciliável com o empírico de que a objetividade moral - por trás da qual se encontra o pensamento da disposição correta do mundo - não pode ser medida na condição dos homens da forma com que existem hoje" (Adorno, 1972, p. 65; Schweppenhäuser, 1995a).

Como Kant colocava o indivíduo no centro de sua ética de convicções, ele o concebeu adequadamente como um indivíduo autônomo, ao mesmo tempo que, no entanto, hipostasiou-o porque não levou em consideração sua mediação heterônoma real. Em contraste, a superação da moralidade em Hegel, segundo Adorno, é bem-dotada de conteúdo de experiência, de forma que o indivíduo a partir de sua própria força dificilmente a consegue mudar, e a ele se antepõe heteronomamente. Mas Hegel torna essa experiência afirmativa. Não critica o bloqueio da vontade racional por relaçōes irracionais, mas dissipa estas como adequada realização daquela. Com isso, ele legitima também a repressão social, à qual os indivíduos estão submetidos, que produz mecanismos de compulsão social e que é transmitida aos indivíduos como uma fatalidade, já que eles não têm uma consciência adequada disso. Com isso, disse Adorno, a teoria filosófico-moral de Hegel deixa-se transformar em uma teoria política, mas num sentido negativo abstrato. "Na medida em que Hegel amplia o conceito do moral para o político, ele o dissolve" (Adorno, 1977, p. 764). Essa dissolução é falsa porque permanece um construto teórico, ao qual não corresponde qualquer mediação real das duas esferas no mundo. Se a moral fosse dissolvida teoricamente, e sem resto, na política, a espontaneidade do indivíduo seria, de novo, conceitual- 
mente tão atenuada quanto, sob as condições alienantes da sociedade, ela de qualquer forma já está, e assim fica a possibilidade de sua realização amplamente limitada.

À proclamação da liberdade realizada corresponde a hipótese de que poderíamos renunciar ao pensamento da moralidade porque seu conteúdo seria suprassumido [aufgehoben], de forma bemsucedida e sem restos, nos costumes políticos. Daí os antípodas Kant e Hegel ficarem como expoentes iguais da verdade e da nãoverdade no terreno filosófico-moral - até que a própria tendência social tomasse uma direção, que pretendesse na prática uma reconciliação do particular e do universal. "A filosofia moral de Kant e a filosofia do direito de Hegel representam duas etapas da autoconsciência burguesa da prática. Divididas entre os pólos do particular e do universal, que aquela consciência separa, ambas são falsas; ambas permanecerão certas quando confrontadas uma com a outra, enquanto não se revelar uma possível forma superior de ação na realidade" (Adorno, 1977, p. 765).

Mas Adorno não se satisfazia com uma apreciação que atribuísse valores idênticos, pois permanecia decididamente um crítico de Hegel. Julgava ideológica a apologia do poder na filosofia da história e do direito de Hegel, que passava soberanamente por cima dos indivíduos e da experiência que estes tinham quanto à prepotência do todo social e historicamente. Adorno tomava partido pelo indivíduo e argumentava por fim claramente contra a reconciliação meramente pretendida do indivíduo e da totalidade, assim como em sua crítica da subsunção da consciência subjetiva sob a norma da moralidade objetiva na forma de norma de direito positiva (Adorno, 1984, p. 394).

O “novo imperativo categórico”

O quanto Adorno concordava com a filosofia moral crítica de Kant - em pormenores isso pode ser verificado em seus detalhados comentários e interpretações nos cursos de 1963 - aparece no teorema ético que, supóe-se, lhe era mais caro: o novo imperativo categórico depois de Auschwitz.

Hitler impôs aos seres humanos, em seu estado de não-liberdade, um novo imperativo categórico: pensar e agir para que Auschwitz nunca mais se repita, para que nada de semelhante possa se repetir. Este imperativo é tão refratário à 
sua fundação como o fora uma vez o dado do imperativo kantiano. Seria um sacrilégio tratá-lo discursivamente: nele se faz sentir corporalmente na moralidade o momento de seu surgimento. (Adorno, 1984, p. 358)

Aqui confluem a reflexão normativa fundadora e aquilo que se relaciona com a situação histórica dos problemas éticos. Adorno formula um novo princípio moral que, em contraste com sua forma kantiana, insere-se numa constelação social e histórica singular.

Um imperativo categórico, que em Kant é expressão de liberdade e de autonomia moral, é “imposto” aos homens. Críticos têm apontado esta contradição de Adorno como um erro (Thyen, 1995), mas perdem assim o ponto central de seu argumento. A confiança fundamentada de Kant em poder realizar a autonomia de indivíduos livres como princípio de socialização dá passagem em Adorno para a consciência de que só se pode tratar agora de combater o estranhamento universal dos homens, causado por suas relaçóes sociais antagônicas, o tanto quanto for possível. A pretensão de validade do imperativo categórico, ela mesma categórica, e que se oferece como incondicional e por conta de si própria, deveria ser garantida em Kant por seu caráter formal, no entanto, valer ao mesmo tempo como um "fato da razão". Em Adorno, tal pretensão de validade acontece pela ligação com a experiência histórica, pelo interesse na abolição do sofrimento, e, por meio de seu caráter heterônomo - heterônomo apenas neste aspecto - não se conduz ad absurdum. Pois cada máxima ética formulada positivamente, independentemente de se relacionar pelo conteúdo com a vida boa, ou formalmente com a ação correta, deve dar meia-volta diante da realidade histórica catastrófica que se manifestou em Auschwitz. Adorno parte do fato de que não mais podemos dizer o que deve ser, mas apenas aquilo que não pode acontecer. Formuladas ex negativo, as proposiçôes crítico-normativas podem se adequar a uma enfática pretensão de validade, que no entanto não é mais "incondicional", mas, condicionada à sua condição de realidade, que, em sentido moral, deveria ser transformada e, pelo interesse em tal mudança, aquém do qual não poderemos recuar. Este interesse, portanto, não é derivável mais uma vez de alguma outra coisa.

Adorno fez uso aqui de um motivo auto-evidente da filosofia moral materialista, e que se orienta pelo conceito, a ser construído, de uma humanidade pacificada. Ele recusou-se a medir seu imperativo moral por critérios discursivos, ou seja, que exigem uma fundamentação argumentativa, mas não porque acreditasse que 
nenhuma fundamentação racional pudesse ser fornecida. Trata-se, em vez disso, do fato de que a exigência de uma fundamentação logicamente incontestável, sem a qual um imperativo moral não poderia aspirar a qualquer validade, feriria o conteúdo da proposição de Adorno e de sua base na experiência; ela seria assim moralmente insustentável. Daí pareceu a Adorno que a pretensão de fundamentação era um "sacrilégio". Isso quer dizer: uma fundamentação discursiva seria possível, mas em vista do indizível do sofrimento, produzido pelos homens, e verificável por todos, seria presunçoso exigir que precisássemos legitimar a reivindicação de sua abolição apenas e especialmente detalhando com recursos discursivos. Disso se segue que o fundamentar por si só não é suficiente para fundar o novo imperativo categórico adorniano, mas não se pode concluir de forma alguma que ele seria por princípio incompatível com a fundamentação teórica, ou que seria enfraquecido ou falsificado por ela. Pelo contrário, boas razões para esse imperativo poderiam ser formuladas, o que por fim Adorno fez; da mesma maneira como Marx quis fundamentar plausivelmente seu teórico-antropológico e emancipatório "imperativo categórico de derrubar todas as relaçóes nas quais o homem é um ser humilhado, oprimido, abandonado e desprezível" (Marx, 1983, p. 385). O único problema é que Adorno não deixou claro o que, na verdade, entendia como "fundamentar" nesse caso - um fundamentar ontológico, um argumentar racional ou uma mistura de ambos. Se se considera esta problemática, na medida em que está ligada ao conceito de fundamentação de Adorno, em conexão com o discurso de fundação na filosofia prática contemporânea, então talvez fique mais claro do que se trata para Adorno. A filosofia analítica mostrou que é logicamente incabível dar uma razão moral como fundamento para a obrigatoriedade de um princípio moral. Ela chegou, no entanto, à falsa conclusão de que não existiria qualquer possibilidade de fundamentação. A isso opõem as éticas neo-aristotélicas seus princípios morais na base do julgamento prático orientado ao bem, assim como as éticas deontológicas kantianas e a ética do discurso deduzem a obrigatoriedade de seus princípios morais de regras formais universalizantes (Steinvorth, 1990, p. 46-61). Mas era justamente um princípio moral afirmativo que Adorno não queria estabelecer, tampouco fundamentá-lo em sua obrigatoriedade. No centro de sua filosofia moral está um imperativo categórico formulado negativamente, que diz o que não pode ocorrer, o que não deve ser. Ele não diz, afirmativamente, como deveria ser evitado o que não deveria ser. Sua 
evidência refere este imperativo à experiência histórica. Ele não pode apelar para qualquer outra instância, sistematicamente, que não seja o impulso moral. Este foi explicado por Adorno no contexto de uma teoria materialista da experiência do sofrimento, que se realiza e se reflete espontaneamente.

No entanto, a rejeição da exigência de fundamentação não é plausível sem reserva. Pois continua aberta a questão de por que toda fundamentação discursiva sempre deveria conduzir à "má infinitude" da "dedução e validade" (Adorno, 1984, p. 281) e se tornar a priori uma racionalização na forma de uma filosofia de princípios éticos. A questão é se Adorno, com a pretensão à fundamentação, também queria rejeitar a pretensão à universalização, pois, se uma proposição moral se afasta de sua fundamentação teórica, dificilmente poderá manter sua obrigatoriedade normativa para todos, o tempo todo, e em qualquer lugar. Mas isso entraria em conflito com a intenção de Adorno em fazer a crítica da filosofia moral a partir do interesse na vida correta. A questão da fundamentação não é realmente respondida, mas é mesmo assim possível pensá-la em conjunto com as intençōes normativas de Adorno. É de se afirmar em primeiro lugar que a filosofia moral negativa pode distinguir-se das fundamentações morais irracionais, porque ela não se baseia em intuições morais destituídas de conceitos e, em segundo lugar, como Schmid Noerr enfatizou, que o "novo imperativo categórico" não é um princípio que "possa ser fundamentado, como um todo, através da moral”, mas apenas "uma Minima Moral da atenção à vida ilesa” (Schmid Noerr, 1999, p. 79).

\section{Teoria crítica do universalismo filosófico-moral}

Ao passo que Bauman nega abstratamente o universalismo filosófico-moral, o problema em Adorno consiste que não há nenhuma teoria do universalismo filosófico-moral, mas apenas alusões a sua dialética imanente. Por exemplo: "A incompatibilidade de todo juízo moral coletivo com a determinação psicológica, que no entanto não dispensa do julgamento de que seja o mal, não surge de lacuna lógica do pensamento, mas de um antagonismo objetivo". O que com isso se indica é que Adorno evidencia a situação aporética, em que a consciência crítica se encontra com sua crítica da ação amoral no sistema nacional-socialista dos campos de concentração. O julgamento moral universalizável que se deve fazer a respeito dos culpados permanece impotente em vista de sua incapacidade psicolo- 
gicamente em estado para agir motivado pela liberdade. Mas disso não segue que sejam inocentados por seu erro de determinação. Também a forma jurídica de executar o Direito, por necessária e moralmente legítima que seja, permaneceria sujeita à lógica da violência, que foi a base para a ação dos criminosos. "Aqui", escreveu Adorno na época do processo de Frankfurt-Auschwitz, "concentra-se a mais nova versão da moral dialética: a absolvição seria a injustiça nua e crua, a justa punição estaria contagiada pelo princípio de violência assassina, em face da qual apenas a resistência é humana" (Adorno, 1984, p. 282).

A inadequação de "todo julgamento moral universal" evidenciase neste ponto extremo; segundo Adorno, contudo, isso não se apresenta apenas nessa ocasião, mas sempre. Lida como um início para uma teoria crítica do universalismo filosófico-moral, isso não significa a negação abstrata da necessária pretensão de generalidade do juízo moral, porém tenta formular o ponto de vista do caráter inevitavelmente aporético que nos é renunciado, porque sem tal pretensão não teríamos nenhum critério de julgamento, mas do critério nunca se segue a compatibilidade das açôes dos indivíduos empíricos com normas morais universalizáveis (Schweppenhäuser, 1999).

As questôes a respeito dos critérios do justo proceder e de um conceito normativo da justiça são hoje de importância central. Pode-se fazer menos com a ética pós-moderna de Bauman que com o método adorniano da crítica imanente, portanto com a negação determinada da filosofia moral e com o auxílio da transição (aristotélica) da ética privada à política, que Adorno recomenda no final de suas preleçôes sobre "O problema da filosofia moral" (Adorno, 1996, p. 261). Isso liga a antiga teoria crítica da moral com as tentativas contemporâneas de dar validade à normatividade crítica como medida da prática social. Axel Honneth mostrou num confronto com Emmanuel Lévinas e Jaques Derrida que o relacionamento de responsabilidade assimétrico, também colocado por Bauman, não pode tornar-se princípio da moral, mesmo que naturalmente possa ser uma experiência elementar da origem da consciência moral no indivíduo (Honneth, 1994, S. 220). Porém, apenas como princípio moral sistemático, o ponto de vista moral universalista pode exigir validade do tratamento eqüitativo, que na modernidade de maneira alguma funcionou apenas como uma ideologia destrutiva de nivelamento equalizador, mas como uma idéia contrafactual de uma justiça que a nós todos obriga a sua 
implementação social universal. Seyla Benhabib tentou, em sua teoria do "universalismo interativo", expandir "o ponto de vista moral" à dimensão da capacidade e prontidão, reverter a perspectiva para a pensar a partir também "do ponto de vista do outro ou dos outros” (Benhabib, 1995, p. 18). A capacidade de universalização não deveria esgotar-se no entendimento discursivo e no pensamento do outro geral, mas deveria também incluir a capacidade de perceber o outro como um outro concreto. Esta seria uma mediação da reflexão filosófico-moral da justiça e da reflexão ética sobre as condições do mundo da vida, sob as quais agimos. Esta tentativa especial de uma mediação do geral com o particular se inspira na questão adorniana básica de "como harmonizar os interesses individuais e as aspirações por felicidade com normas objetivas, obrigatórias para o gênero humano". Sem a continuação de um trabalho a partir das considerações de Adorno dificilmente se poderia, hoje, pensar em tentativas de uma transformação que acolha autocriticamente o universalismo filosófico-moral.

Recebido e aprovado em maio de 2003.

\section{Notas}

1. N.T.: Deontologia: o estudo dos princípios, fundamentos e sistemas da moral.

2. Grifos do autor no texto.

3. N.T.: Ethos: fundamentos da vida moral de um homem ou da sociedade.

4. N.T.: De Tartufo, personagem da comédia homônima de Molière; homem hipócrita, falso devoto.

Referências bibliográficas

ADORNO, T.W. Soziologische Schriften I. In: Adorno, T.W. Gesammelte Schriften. Vol. 8. Frankfurt am Main: Suhrkamp, 1972.

ADORNO, T.W. Marginalien zu Theorie und Praxis. In: Adorno, T.W. Gesammelte Schriften. Vol. 10.2. Frankfurt am Main: Suhrkamp, 1977, p. 759-782.

ADORNO, T.W. Minima Moralia: Reflexionen aus dem Beschädigten Leben. In: Adorno, T.W. Gesammelte Schriften. Vol. 4. Frankfurt am Main: Suhrkamp, 1980. 
ADORNO, T.W. Negative Dialektik. In: Adorno, T.W. Gesammelte Schriften. Vol. 6. Frankfurt am Main: Suhrkamp, 1984.

ADORNO, T.W. Probleme der Moralphilosophie (1963). In: AdorNO, T.W. Nachgelassene Schriften: abt. 4, Vorlesungen. Vol. 10. Frankfurt am Main: Suhrkamp, 1996.

BAUMAN, Z. Moderne und Ambivalenz: das Ende der Eindeutigkeit. Hamburg: Junius, 1992 (engl.: Modernity and ambivalence, 1991).

BAUMAN, Z. Postmoderne Ethik. Hamburg: Hamburger, 1995 (engl.: Postmodern ethics, 1993).

BENHABIB, S. Kritik, Norm und Utopie: die normativen Grundlagen der kritischen Theorie. Frankfurt am Main: Fischer, 1992 (engl.: Critique, norm and utopia. New York: Columbia University, 1986).

BENHABIB, S. Selbst im Kontext: kommunikative Ethik im Spannungsfeld von Feminismus, Kommunitarismus und Postmoderne. Frankfurt am Main: Suhrkamp, 1995 (engl.: Situating the self).

BONß, W. Die uneindeutige Moderne: Anmerkungen zu Zygmunt Bauman. Mittelweg 36, Hamburg, n. 4, p. 23-32, 1993.

BRECHT, B. Gesammelte Werke. Vol. 10. Frankfurt am Main: Suhrkamp, 1982.

BRUNKHORST, H. Theodor W. Adorno: Dialektik der Moderne. München: Piper, 1990.

HABERMAS, J. Der philosophische Diskurs der Moderne: zwölf Vorlesungen. Frankfurt am Main: Suhrkamp, 1986.

HAUG, W.F. Marx, Ethik und ideologische Formbestimmtheit von Moral. In: Angehrn, E.; Lohmann, G. (Ed.). Ethik und Marx: Moralkritik und normative Grundlagen der Marxschen Theorie. Königstein/Ts.: Hain Verlag bei Athenäum, 1986, p. 36-57.

HONNETH, A. Das Andere der Gerechtigkeit: Habermas und die ethische Herausforderung der Postmoderne. Deutsche Zeitschrift für Philosophie, Berlin, vol. 42, n. 2, p. 195-220, 1994.

HORKHEIMER, M.; ADORNO, T.W. Dialektik der Aufklärung: philosophische Fragmente. In: Adorno, T.W. Gesammelte Schriften. Vol. 3. Frankfurt am Main: Suhrkamp, 1981. 
HORKHEIMER, M.; ADORNO, T.W.; GADAMER, H.G. Über Nietzsche und uns. Zum 50: Todestag des Philosophen. In: HorkHEIMER, M. Gesammelte Schriften. Vol. 13. Frankfurt am Main: FischerTaschenbuch, 1989, p. 111-120.

LUHMANN, N. Ethik als Reflexionstheorie der Moral. In: LUHMANN, N. Gesellschaftsstruktur und Semantic. Vol. 3. Frankfurt am Main, Suhrkamp, 1989, p. 358-447.

MARX, K. Zur Kritik der hegelschen Rechtsphilosophie: Einleitung. In: Marx, K.; Engels, F. Werke. Berlin: Dietz, 1983, p. 378-391.

NIETZSCHE, F. Werke in drei Bänden. Vols. 1/2. München: Hanser, 1977.

ROUSSEAU, J.-J. Über den Ursprung der Ungleichheit unter den Menschen. In: Rousseau, J.-J. Schriften zur Kulturkritik. Hamburg: Meiner, 1983.

SCHMID NOERR, G. Moralischer Impuls und gesellschaftliche Reflexion: das Verhältnis der kritischen Theorie zur Mitleidsethik. In: Schmid Noerr, G. Gesten aus Begriffen: Konstellationen der kritischen Theorie. Frankfurt am Main: Fischer-Taschenbuch, 1997, p. 153-197.

SCHMID NOERR, G. Kritik der Ethik in moralischer Absicht: Anläßlich neuerer Versuche, Adornos Ethik zu Rekonstruieren. Allgemeine Zeitschrift für Philosophie, Stuttgart, vol. 24, n. 1, p. 69$80,1999$.

SCHOPENHAUER, A. Preisschrift über die Grundlage der Moral. In: Schopenhauer, A. Zürcher Ausgabe. Vol. 6. Zürich: Diogenes, 1977.

SCHWEPPENHÄUSER, G. Nietzsches Überwindung der Moral: zur Dialektik der Moralkritik in Jenseits von Gut und Böse und in der Genealogie der Moral. Würzburg: Königshausen \& Neumann, 1988.

SCHWEPPENHÄUSER, G. Ethik nach Auschwitz: Adornos negative Moralphilosophie. Hamburg: Argument-Verlag, 1993.

SCHWEPPENHÄUSER, G. Kritische Moralphilosophie als negativer Universalismus: zum Problem der Normativität bei Adorno. In: SchweppenhäUser, G. Soziologie im Spätkapitalismus: zur Gesellschaftstheorie Theodor W. Adornos. Darmstadt: Wissenschaftliche Buchgesellschaft, 1995, p. 244-258. 
SCHWEPPENHÄUSER, G. Die selbstdestruktion des KulturÜberichs: Überlegungen zu den Grundlagen von Kultur - und Moralkritik bei Adorno. In: SCHWeppenhäUser, G.; WischKe, M. (Ed.). Impuls und negativität: Ethik und Ästhetik bei Adorno. Hamburg: Argument-Verlag, 1995a., p. 198-214.

SCHWEPPENHÄUSER, G. Das Unbehagen an der Moral: zur Kritik der Ethik bei Adorno und Bauman. Das Argument, vol. 41, n. 4, p. 513-526, 1999.

STEINVORTH, U. Klassische und moderne Ethik: Grundlinien einer materialen Moraltheorie. Hamburg: Rowohlt, 1990.

THYEN, A. Metaphysikritik und Ethik bei Theodor W. Adorno und Emmanuel Lévinas. In: Schweppenhäuser, G.; Wischke, M. (Ed.). Impuls und negativität: Ethik und Ästhetik bei Adorno. Hamburg: Argument-Verlag, 1995, p. 136-151.

WITTGENSTEIN, L. Philosophische Untersuchungen. In: Wittgenstein, L. Werkausgabe. Vol. 1. Frankfurt am Main: Suhrkamp, 1995. 